Agro-Science Journal of Tropical Agriculture, Food, Environment and Extension Volume 13 Number 1 January 2014 pp. 18 - 25

ISSN III9-7455

\title{
ASSESSMENT OF THE NUTRIENT CONTENTS OF BROILER STARTER AND FINISHER DIETS IN NIGERIA
}

\author{
*Malomo, G. A. ${ }^{1}$, Suleiman, Z. G. ${ }^{2}$, Bolu. S. A. ${ }^{3}$ and T. A. Egberuare ${ }^{1}$ \\ ${ }^{1}$ Livestock Research Division, Coordination of Technical Research Programme, \\ ${ }^{2}$ Bureau of Gender and Youths in Agricultural Research \& Innovation \\ Agricultural Research Council of Nigeria (ARCN), Abuja \\ ${ }^{3}$ Animal Production Department, University of Ilorin, Ilorin, Nigeria \\ *digabby@yahoo.com
}

\begin{abstract}
The study was conducted to assess the proximate composition and amino acid profiles of six (6) commercial broiler starter and finisher diets. Four samples of each feed type were procured from different feed vendors within Abuja metropolis and subjected to proximate and amino acid analyses. The dry matter, crude protein, crude fibre, crude fat and ash contents of broiler starter and finisher diets were observed to be within the levels of 92.2 -94.4\%, 21.5-24.6\%, $4.0-8.7 \%, 5.5-8.7 \%$ and $7.9-12.0 \%$ and 91.64-94.38\%, 19.06-22.63\%, 4.41-8.77\%, $5.37-8.41 \%$ and $7.87-11.25 \%$, respectively, and were within the ranges quoted on the labels of the feeds analyzed. The results also showed that there was no significant $(P>0.05)$ difference in the crude protein (4), arginine, methionine, isoleucine, threonine and valine contents of the broiler starter diets compared with the vatusin the nutrient tables of NRC., Except for methionine+cystein which was lower $(P<0.05)$, most of the finished starter diets had significantly $(P<0.05)$ higher histidine, lysine, proline, phenylalaline, phenylalaline+thyrocine and glycine+serine values than those recommended by NRC for broiler aged 1-3 weeks. Similarly, all test broiler starter diets had superior $(P<0.05) C P$ and amino acids profile compared with the NRC recommendation for broilers aged 3-6 weeks. While crude protein, arginine, isoleucine, methionine, lysine, threonine, methionine+cystein and phenylalanine contents were similar $(P>0.05)$, leucine, valine, phenylalaline +thyrocine and glycine+serine values of the test finisher diets were significantly $(P<0.05)$ different from NRC recommendation for broilers aged 3-6 weeks. Except for arginine, isoleucine and threonine which were similar $(P<0.05)$ to NRC requirement table for broilers aged 6-8 weeks, $C P$ and the other amino acid vatus of the test finisher diets were higher $(P<0.05)$. Although, estimated chemical scores of analyzed diets revealed a generally high trend, methionine plus cystine appeared limiting in the broiler starter diets compared with recommended levels for birds aged 1-3 weeks; threonine, valine or isoeucine may be limiting in some broiler finisher diets when compared with requirement for broilers aged 3-6 weeks.
\end{abstract}

Keywords: Broiler starter, broiler finisher, finished feeds, proximate composition, amino acid profile

\section{INTRODUCTION}

The livestock sector is crucial to the socio-economic development of Nigeria, contributing about $13 \%$ of agricultural GDP between 1996 and 2000 (Manyong et al., 2005). There is also a general agreement among agriculturists and nutritionists, that if developed, the poultry industry has the potential of being the fastest means of bridging the potential nutrient deficiency gap presently prevailing in the country (Ikpi and Akinwumi, 1981). With an estimated population of
192.3 million chickens (FAOSTAT, 2012), the poultry sector is the fastest growing major sub-sector of the livestock industry in Nigeria and having an annual average growth rate of $4.92 \%$ in 2001 to 2010, compared with $1.02 \%, 2.50 \%, 2.40 \%$ and $4.15 \%$ for cattle, goat, sheep and pig respectively for the same period. Chicken meat output also ranked third after beef and goat meat in Nigeria for 2010 (FAOSTAT, 2012). In spite of these prospects, productivity within 
the poultry sub-sector in Nigeria has been constrained by poor nutrition and diseases (Adene and Oguntade, 2006), with yield per carcass weight of chicken still estimated at $1 \mathrm{~kg}$ compared with $1.5 \mathrm{~kg}$ and $1.3 \mathrm{~kg}$ in Canada and Egypt, respectively (FAOSTAT, 2012).

Feed is one of the most important inputs in poultry production accounting for about $75 \%$ of the total cost of production (Nakaue and Arscott, 1991), hence the need to ensure its quality. Feed quality in poultry production could be specified on the basis of nutritional value of individual feed components and non-nutritional contaminants that may reduce the nutritional value resulting in adverse health conditions in the animals (Okoli et al., 2006). There have been concerns about the nutritional quality of commercial feeds in Nigeria due to high cost of some critical inputs, which encouraged increased use of lower quality and cheaper feed ingredients, with wheat bran accounting for $15-28 \%$ of feed formulation, while soya bean inclusion is generally low (USDA, 2002). While many poultry producers prefer toll milled or protein concentrates to finished feeds, a substantial number of the producers still depend on commercial feeds. This may be one of the contributing factors to the considerable increase in the number of finished poultry feed available in the market in recent time. Thus, considering the high proportion of production expenses covered by feeding cost, the importance of maintaining feed quality and ensuring value for money cannot be over-emphasized.

Poultry diets are primarily composed of a mixture of several feedstuffs, which supply essential nutrients for the growth, reproduction and health of the birds. The quality of the proteins in the feed ingredients depends on the level, balance and digestibility of essential amino acids in the final mixed feed rather than the dietary protein level alone (Aviagen, 2009). The supply of amino acids in the form of protein to poultry diets represents a major cost component of such diets (Corzo et al., 2004; Eits et al., 2005). Thus, an increasing use of wheat offal and a strategic reduction of soya beans in commercial diets mainly motivated by attempts at cutting down on the cost of production has been reported (USDA, 2002) and this could affect the nutritional quality of the finished feed. Optimum performance in birds requires that amino acids be supplied in an adequate and consistent manner (Briyen and Li, 2004). Similarly, provision of the recommended nutrient density for broilers would promote optimal growth, particularly during the early stage of life (Aviagen, 2009), while inadequate dietary amino acids are major contributors to reduction of growth/productivity and a less efficient utilization of protein in birds (NRC, 1994). Inadequate supply of essential amino acids may result in increased FCR, reduced breast muscle and reduced carcass quality in birds (NRC, 1994). The present study evaluated and compared the proximate composition and amino acid profiles of six (6) different commercial broiler starters and finisher diets with the recommended values in the National Research Council (NRC) nutrient tables. It also attempted to estimate the quality of the diets using the chemical score of amino acids, which was used to identify the possible limiting amino acid in the test diets.

\section{MATERIALS AND METHODS test diets \\ Sample collection and chemical analysis of}

Feed samples of six (6) Commercial Broiler starter and finisher feeds were procured from different commercial feed vendors at Abuja. The feed samples were procured at three (3) locations within the metropolis to ensure differences in batch. These were subjected to proximate and amino acid analysis. The proximate analysis was carried out according to the methods described by AOAC (1990). The amino acid profiles of the diets were also analyzed using the procedure described by Llames and Fontaine (1994).

Chemical score of dietary amino acids

Chemical score (CS), which gives an estimate of the biological value of the dietary protein of analyzed feeds, were calculated using the formulae:

$\mathrm{CS}=($ Amino acid in test feed $(\mathrm{g} / 16 \mathrm{~g} \mathrm{~N}) /$ Amino acid in ideal protein $(\mathrm{g} / 16 \mathrm{~g} \mathrm{~N})) * 100$

Amino acid with the lowest score below 100 is the limiting amino acid (Miller, 2004). This was used to identify the possible limiting amino acids in the diets.

Computation of the chemical score of the diets was done at three levels, that is, one for the starter and two for finishers. The amino acid profiles of test finished broiler starter diets were scored chemically against the recommendations of NRC for broilers aged 0 to 3 and 3 to 6 weeks. Chemical scores for the commercial broiler commercial diets were computed and compared with NRC's recommendations for broilers aged 3 to 6 and 6-8 weeks. This was done because the common practice in Nigeria is to change broilers from starter to finisher diets at 3 to 5 weeks of age.

\section{Statistical analysis}

Mean data for the dietary nutrients and chemical scores of the test diets were statistically compared against NRC (1994) recommended levels using $16^{\text {th }}$ edition of GenStat (2013).

\section{RESULTS AND DISCUSSION}

Mean proximate composition of the finished diets as analyzed is presented in Table 1 . The dry matter (DM), crude protein $(\mathrm{CP})$, crude fibre $(\mathrm{CF})$, crude fat and ash contents of broiler starter feeds were observed to be within the range of 92.2 to $94.4 \%, 21.5$ to $24.6 \%, 4.0$ 
to $8.7 \%, 5.5$ to $8.7 \%$ and 7.9 to $12.0 \%$, respectively. Also, 91.64 to $94.38 \%, 19.06-22.63 \%, 4.41$ to $8.77 \%$, 5.37 to $8.41 \%$ and 7.87 to $11.25 \%$ were the ranges obtained for DM, CP, CF, fat and ash contents of the test finisher diets, respectively. The observed values were within the ranges declared on the labels of the feeds for all the nutrient constituents analyzed. The crude protein and amino acid profile of the broiler starter feeds as analyzed are presented in Table 2. The results showed that there was no significant $(\mathrm{P}>0.05)$ difference in the crude protein, arginine, methionine, isoleucine, threonine and valine contents of the commercial broiler diets compared with the levels recommended by NRC (1994). On the other hand, except for methionine+cystein which was significantly lower $(\mathrm{P}<0.05)$, most of the commercial broiler diets analyzed had significantly $(\mathrm{P}<0.05)$ higher histidine, lysine, proline, phenylalaline, phenylalaline+thyrocine and glycine+serine values than those recommended by NRC (1994) for broilers aged 1 to 3 weeks. The findings of the present study is consistent with Patterson (2001) who reported that $23 \%$ crude protein diets supplemented with methionine and lysine had many other amino acids in excess of the birds' requirements.

Table 1: Proximate composition (\%) of some commercial broiler starter and finisher feeds

\begin{tabular}{|c|c|c|c|c|c|}
\hline Feeds/Nutrients & Dry matter & Crude protein & Crude fibre & Crude fat & Ash \\
\hline \multicolumn{6}{|l|}{ Starter } \\
\hline $\mathrm{CF}_{1}$ & 93.4 & 21.5 & 5.0 & 8.6 & 10.4 \\
\hline $\mathrm{CF}_{2}$ & 92.4 & 22.8 & 4.0 & 7.3 & 9.0 \\
\hline $\mathrm{CF}_{3}$ & 92.5 & 23.1 & 5.3 & 7.5 & 7.9 \\
\hline $\mathrm{CF}_{4}$ & 92.2 & 21.7 & 5.7 & 5.5 & 12.0 \\
\hline $\mathrm{CF}_{5}$ & 94.4 & 22.9 & 7.8 & 8.7 & 8.8 \\
\hline $\mathrm{CF}_{6}$ & 94.2 & 24.6 & 8.7 & 5.7 & 9.1 \\
\hline \multicolumn{6}{|l|}{ Finisher } \\
\hline $\mathrm{CF}_{1}$ & 92.45 & 20.56 & 5.30 & 7.53 & 7.87 \\
\hline $\mathrm{CF}_{2}$ & 93.05 & 22.63 & 4.73 & 7.87 & 9.45 \\
\hline $\mathrm{CF}_{3}$ & 92.34 & 21.19 & 4.41 & 8.41 & 10.95 \\
\hline $\mathrm{CF}_{4}$ & 91.64 & 20.56 & 5.60 & 7.75 & 11.25 \\
\hline $\mathrm{CF}_{5}$ & 93.75 & 19.06 & 7.49 & 5.37 & 7.49 \\
\hline $\mathrm{CF}_{6}$ & 94.38 & 21.18 & 8.77 & 5.84 & 8.77 \\
\hline
\end{tabular}

Note: $\mathrm{CF}=$ Finished feed

Table 2: Crude protein and amino acids (\%) of commercial broiler starters compared with NRC (1994) recommendations

\begin{tabular}{|c|c|c|c|c|c|c|c|c|c|}
\hline Nutrients & $\mathrm{CF}_{1}$ & $\mathrm{CF}_{2}$ & $\mathrm{CF}_{3}$ & $\mathrm{CF}_{4}$ & $\mathrm{CF}_{5}$ & $\mathrm{CF}_{6}$ & $\mathrm{NRC}$ & SEM & P-value \\
\hline Crude protein & 21.54 & 22.81 & 23.10 & 21.69 & 22.89 & 24.63 & 23.00 & 0.46 & 0.65 \\
\hline Arginine & 1.11 & 1.17 & 1.15 & 1.20 & 1.15 & 1.67 & 1.25 & 0.09 & 0.93 \\
\hline Glysine+Serine & 1.58 & 1.69 & 1.63 & 1.50 & 1.47 & 1.88 & $1.25 * *$ & 0.06 & 0.002 \\
\hline Histidine & 0.51 & 0.53 & 0.55 & 0.52 & 0.63 & 0.59 & $0.35 * *$ & 0.02 & $<0.001$ \\
\hline Isoleucine & 0.76 & 0.82 & 0.76 & 0.78 & 0.88 & 0.80 & 0.80 & 0.02 & 0.88 \\
\hline Leucine & 1.51 & 1.78 & 1.77 & 1.71 & 1.98 & 1.73 & $1.20 * *$ & 0.06 & $<0.001$ \\
\hline Lysine & 1.11 & 1.15 & 1.14 & 1.16 & 1.17 & 1.24 & $1.10^{*}$ & 0.02 & 0.018 \\
\hline Methionine & 0.51 & 0.52 & 0.52 & 0.52 & 0.51 & 0.47 & 0.50 & 0.02 & 0.665 \\
\hline Met+Cystine & 0.77 & 0.81 & 0.82 & 0.78 & 0.73 & 0.83 & $0.90 * *$ & 0.02 & $<0.001$ \\
\hline Phenylalanine & 1.11 & 1.13 & 1.08 & 1.09 & 1.08 & 1.02 & $0.72 * *$ & 0.02 & $<0.001$ \\
\hline Phenyla+Tyro & 1.76 & 1.95 & 1.86 & 1.84 & 1.78 & 1.89 & $1.34 * *$ & 0.03 & $<0.001$ \\
\hline Proline & 0.69 & 0.68 & 0.66 & 0.72 & 0.78 & 0.97 & $0.6^{*}$ & 0.05 & 0.03 \\
\hline Threonine & 0.73 & 0.74 & 0.76 & 0.73 & 0.75 & 0.87 & 0.80 & 0.02 & 0.154 \\
\hline Valine & 0.86 & 0.99 & 0.96 & 0.88 & 1.01 & 1.20 & 0.90 & 0.05 & 0.155 \\
\hline
\end{tabular}


Also, compared with NRC (1994) recommendations for broilers aged 3 to 6 weeks of age, all the finished broiler starter diets showed superior $(\mathrm{P}<0.05)$ protein and amino acid profile. However, while the nutrient similar $(\mathrm{P}>0.05)$ to the levels recommended by NRC (1994) for broilers aged 3-6 weeks while methionine, leucine, valine, phenylalaline+thyrocine and glycine+serine values of the test diets were significantly $(\mathrm{P}<0.05)$ different and higher for most of the test diets. Significantly higher amino acids may be valuable for broilers in the tropical part of the world, particularly considering the relatively high ambient temperature. It has been noted that the NRC amino acid recommendations for chickens are applicable where the temperature is normal $\left(18-24^{\circ} \mathrm{C}\right)$ and these requires to be increased in higher temperature environment to compensate for reduced dietary intake (NRC, 1994). However, this may at the same time support excessive nitrogen excretion in the broilers. The nutrient profile of the finisher diets compared with NRC (1994) recommendations for broilers aged 6 to 8 weeks are profile of test finisher diets were compared with recommendations for broilers aged 3 to 6 weeks, crude protein, arginine, isoleucine, lysine, threonine, methionine+cystein and phenylalanine contents were presented in Table 4 . The results showed that while arginine, isoleucine and threonine contents of the diets were similar the NRC (1994) recommendations for broilers aged 6 to 8 weeks, crude protein and the other amino acids analyzed were significantly $(\mathrm{P}<0.05)$ higher in most of the diets. Salehifar et al. (2012) evaluated the amino acid requirements for broilers during the finisher phase. They reported that digestible Lysine, Methionine, Methionine+Cystein, Threoline, Isoleucine, Arginine, Trytophan, Leucine and Valine requirements for male and female broiler were 1.04, $0.538,0.842,0.696,0.793,1.255,0.223,1.553,0.884$ and $0.984,0.504,0.797,0.659,0.744, \quad 1.175$, $0.209,1.493,0.836$ in finisher period, respectively. The values are higher than the recommendations of NRC and demonstrated that the nutrients demands of broilers may be higher in the tropics.

Table 3: Crude protein and amino acids (\%) of commercial broiler finishers compared with NRC (1994) recommendations for birds aged 3-6 weeks

\begin{tabular}{|c|c|c|c|c|c|c|c|c|c|}
\hline Nutrients & $\mathrm{CF}_{1}$ & $\mathrm{CF}_{2}$ & $\mathrm{CF}_{3}$ & $\mathrm{CF}_{4}$ & $\mathrm{CF}_{5}$ & $\mathrm{CF}_{6}$ & NRC & SEM & P-value \\
\hline Crude protein & 20.56 & 22.63 & 21.19 & 20.56 & 19.06 & 21.17 & 20.00 & 0.48 & 0.129 \\
\hline Arginine & 1.10 & 1.10 & 1.13 & 1.10 & 0.99 & 1.19 & 1.10 & 0.05 & 0.684 \\
\hline Glysine+Serine & 1.41 & 1.55 & 1.56 & 1.45 & 1.24 & 1.69 & $1.14 * *$ & 0.06 & 0.003 \\
\hline Histidine & 0.50 & 0.47 & 0.49 & 0.49 & 0.59 & 0.72 & $0.32 * *$ & 0.04 & 0.002 \\
\hline Isoleucine & 0.78 & 0.74 & 0.85 & 0.82 & 0.59 & 0.56 & 0.73 & 0.07 & 0.633 \\
\hline Leucine & 1.63 & 1.57 & 1.61 & 1.52 & 1.78 & 1.62 & $1.09 * *$ & 0.04 & $<0.001$ \\
\hline Lysine & 1.04 & 1.07 & 1.01 & 1.01 & 0.99 & 1.07 & 1.00 & 0.02 & 0.07 \\
\hline Methionine & 0.46 & 0.51 & 0.57 & 0.47 & 0.41 & 0.45 & $0.38 * *$ & 0.04 & 0.007 \\
\hline Met+Cystine & 0.75 & 0.76 & 0.72 & 0.77 & 0.69 & 0.71 & 0.72 & 0.02 & 0.346 \\
\hline Phenylalanine & 0.99 & 1.07 & 1.06 & 0.65 & 0.57 & 0.65 & 0.65 & 0.10 & 0.113 \\
\hline Phenyla+Tyro & 1.65 & 1.83 & 1.83 & 1.62 & 1.49 & 1.65 & $1.22 * *$ & 0.05 & $<0.001$ \\
\hline Proline & 0.65 & 0.68 & 0.64 & 0.58 & 0.59 & 0.67 & $0.55^{* *}$ & 0.02 & 0.004 \\
\hline Threonine & 0.69 & 0.68 & 0.73 & 0.66 & 0.68 & 0.65 & 0.74 & 0.02 & 0.10 \\
\hline Valine & 0.82 & 0.68 & 0.85 & 0.87 & 0.92 & 1.06 & $0.82 *$ & 0.05 & 0.04 \\
\hline
\end{tabular}

Note: $\mathrm{CF}=$ commercial feed; $\mathrm{P}<0.05$; *significant at $\mathrm{P}<0.05$ for values on the same row; $* *$ Significant at $\mathrm{P}<0.01$ for values on the same row

Table 4: Crude protein and amino acids (\%) of commercial broiler finishers compared with NRC (1994) recommendations for birds aged 6-8 weeks

\begin{tabular}{|c|c|c|c|c|c|c|c|c|c|}
\hline Nutrients & $\mathrm{CF}_{1}$ & $\mathrm{CF}_{2}$ & $\mathrm{CF}_{3}$ & $\mathrm{CF}_{4}$ & $\mathrm{CF}_{5}$ & $\mathrm{CF}_{6}$ & $\mathrm{NRC}$ & SEM & P-value \\
\hline Crude protein & 20.56 & 22.63 & 21.19 & 20.56 & 19.06 & 21.17 & $18.00 * *$ & 0.48 & 0.002 \\
\hline Arginine & 1.10 & 1.10 & 1.13 & 1.10 & 0.96 & 1.19 & 1.00 & 0.05 & 0.144 \\
\hline Glysine+Serine & 1.41 & 1.55 & 1.56 & 1.45 & 1.24 & 1.69 & $0.97 * *$ & 0.06 & $<0.001$ \\
\hline Histidine & 0.50 & 0.47 & 0.49 & 0.49 & 0.59 & 0.72 & $0.27 * *$ & 0.04 & $<0.001$ \\
\hline Isoleucine & 0.78 & 0.74 & 0.85 & 0.82 & 0.59 & 0.56 & 0.62 & 0.07 & 0.295 \\
\hline Leucine & 1.63 & 1.57 & 1.61 & 1.52 & 1.78 & 1.62 & $0.93 * *$ & 0.04 & $<0.001$ \\
\hline Lysine & 1.04 & 1.07 & 1.01 & 1.01 & 0.99 & 1.07 & $0.85 * *$ & 0.01 & $<0.001$ \\
\hline Methionine & 0.46 & 0.51 & 0.57 & 0.47 & 0.41 & 0.45 & $0.32 * *$ & 0.02 & $<0.001$ \\
\hline Met+Cystine & 0.75 & 0.76 & 0.72 & 0.77 & 0.69 & 0.71 & $0.60 * *$ & 0.013 & $<0.001$ \\
\hline Phenylalanine & 0.99 & 1.07 & 1.06 & 0.65 & 0.57 & 0.65 & $0.65^{*}$ & 0.01 & 0.035 \\
\hline Phenyla+Tyro & 1.65 & 1.83 & 1.83 & 1.62 & 1.49 & 1.65 & $1.04 * *$ & 0.05 & $<0.001$ \\
\hline Proline & 0.65 & 0.68 & 0.64 & 0.58 & 0.59 & 0.67 & $0.46 * *$ & 0.02 & $<0.001$ \\
\hline Threonine & 0.69 & 0.68 & 0.73 & 0.66 & 0.68 & 0.65 & 0.68 & 0.02 & 0.768 \\
\hline Valine & 0.82 & 0.68 & 0.85 & 0.87 & 0.92 & 1.06 & $0.70^{*}$ & $0.05^{*}$ & 0.022 \\
\hline
\end{tabular}


Calculated chemical scores (CS) of protein in the commercial starter and finisher diets are presented in Tables 5, $6 \& 7$. In this study, CS gives estimates of the biological values of the diets with respect to the recommended dietary amino acids levels by NRC (1994). The chemical scores of amino acids ranged from 86 to $154 \%, 90$ to $157 \%, 91$ to $157 \%, 87-151 \%$, 81 to $180 \%$ and 82 to $169 \%$ for commercial starter diets $\mathrm{CF}_{1}, \mathrm{CF}_{2}, \mathrm{CF}_{3}, \mathrm{CF}_{4}, \mathrm{CF}_{5}$ and $\mathrm{CF}_{6}$, respectively (Table 5). The results also showed that judging by $\mathrm{CS}$ estimates, methionine + cystein may be the limiting amino acid in all the diets as it had the least score $(\mathrm{P}<0.05)$ below 100 for the amino acids in all the test starter diets compared. The chemical score data followed the same trend with the analyzed methionine + cystein values for the starter diets which was significantly $(\mathrm{P}<0.05)$ lower than the recommended level by NRC (1994). However, this may not be of any perceived serious consequences as methionine plus cystine ratio in the test starter diets to the recommended level ranged from $82: 100$ to $91: 100$ in the present study. Up to $60 \%$ reduction in recommended dietary methionine plus cystine has been achieved without any adverse effects on the performance of the birds (Sugahara et al., 1969). Improved weight gain in chicken was reported when methionine+cystine, leucine, lysine, and arginine were reduced individually to $60 \%$ of their requirements as opposed to when the amino acids were decreased collectively (Sugahara et al., 1969). Broiler finisher diets analyzed had chemical score estimates ranging from 93 to $156 \%, 83$ to $165 \%, 99$ to $163 \%, 89-153 \%$,
67 to $163 \%$ and 69 to $224 \%$ for $\mathrm{CF}_{1}, \mathrm{CF}_{2}, \mathrm{CF}_{3}, \mathrm{CF}_{4}$, $\mathrm{CF}_{5}$ and $\mathrm{CF}_{6}$, respectively (Table 6). The results indicate that based on chemical scoring of each finisher diet against recommended requirement for broilers aged 3 to 6 weeks, valine may be the limiting amino acid in $\mathrm{CF}_{2}$, threonine in $\mathrm{CF}_{4}$; and isoleucine in $\mathrm{CF}_{5}$ and $\mathrm{CF}_{6}$, respectively. No amino acids were suspected to be limiting in $\mathrm{CF}_{1}$ and $\mathrm{CF}_{3}$. Sugahara et al. (1969) reported weight loss with individual reduction of phenylalanine, tyrosine, tryptophan, isoleucine, valine and threonine in broilers. The implication of this finding is that except for diets 1 and 3, it may not be advisable to switch broilers to finisher diets at 3 weeks of age except the amino acids in diets were balanced with the synthetic form of the limiting ones. However, this needs to be subjected to biological trials with live broilers.

In Nigeria, as in many countries, synthetic form of amino acids used to balance requirement is mainly limited to methionine and lysine; it is not a common practice to utilize other synthetic form of amino acids like threonine, isoleucine, valine, etc. (Neto et al., 2000; Bregendhahl et al., 2002). However, synthetic forms of these amino acids are available commercially and in sufficient quantities that would make their use in broiler feeds feasible (Burnham, 2003). Owing to the order of threonine, isoleucine and valine as limiting amino acid after methionine and lysine, it may become imperative for commercial feed producers to consider the use of their synthetic forms in poultry feed, when found necessary (Burnham, 2003).

Table 5: Estimated chemical score $(\%)$ of protein in analyzed commercial broiler starter diets*

\begin{tabular}{lcccccccc}
\hline Nutrients & $\mathrm{CF}_{1}$ & $\mathrm{CF}_{2}$ & $\mathrm{CF}_{3}$ & $\mathrm{CF}_{4}$ & $\mathrm{CF}_{5}$ & $\mathrm{CF}_{6}$ & $\mathrm{SEM}$ & $\mathrm{P}$-Value \\
\hline Arginine & 89 & 94 & 92 & 96 & 92 & 134 & 11.65 & $<0.001$ \\
Glysine+Serine & 127 & 135 & 130 & 120 & 118 & 150 & 4.75 & 0.001 \\
Histidine & 146 & 151 & 157 & 149 & 180 & 169 & 5.40 & $<0.001$ \\
Isoleucine & 95 & 103 & 95 & 98 & 110 & 100 & 7.63 & 0.07 \\
Leucine & 126 & 148 & 148 & 143 & 165 & 144 & 5.10 & $<0.001$ \\
Lysine & 101 & 105 & 104 & 106 & 106 & 113 & 1.62 & 0.016 \\
Methionine & 102 & 104 & 104 & 104 & 102 & 94 & 8.66 & 0.051 \\
Met+Cystine & $86^{* *}$ & $90^{* *}$ & $91^{* *}$ & $87^{* *}$ & $86^{* *}$ & $82^{* *}$ & 7.49 & 0.002 \\
Phenylalanine & 154 & 157 & 150 & 151 & 150 & 142 & 2.06 & $<0.001$ \\
Phenyla+Tyro & 131 & 146 & 139 & 137 & 133 & 141 & 2.23 & $<0.001$ \\
Proline & 115 & 113 & 110 & 120 & 130 & 162 & 7.93 & 0.025 \\
Threonine & 91 & 93 & 95 & 91 & 94 & 108 & 8.24 & 0.006 \\
Valine & 96 & 110 & 107 & 98 & 112 & 113 & 8.93 & 0.003 \\
\hline Suspected & Met + & Met + & Met + & Met + & Met + & Met + & & \\
limiting amino & cystine & cystine & cystine & cystine & cystine & cystine & & \\
acid in diet & & & & & & & & \\
\hline
\end{tabular}

*Note: Chemical scores based on NRC (1994) requirements for broilers aged 1-3 week. ** CS Values significantly (P<0.05) lower than the recommended requirement (100) for the amino acid. 
Table 6: Estimated chemical score $(\%)$ of protein in analyzed finished broiler finisher starter diets compared with recommendation for birds aged 3-6 weeks*

\begin{tabular}{|c|c|c|c|c|c|c|c|c|}
\hline Nutrients & $\mathrm{CF}_{1}$ & $\mathrm{CF}_{2}$ & $\mathrm{CF}_{3}$ & $\mathrm{CF}_{4}$ & $\mathrm{CF}_{5}$ & $\mathrm{CF}_{6}$ & SEM & P-value \\
\hline Arginine & 100 & 100 & 103 & 100 & 90 & 108 & 7.58 & 0.041 \\
\hline Glysine+Serine & 123 & 136 & 137 & 127 & 109 & 148 & 5.50 & 0.003 \\
\hline Histidine & 156 & 147 & 153 & 153 & 184 & 224 & 12.13 & 0.002 \\
\hline Isoleucine & 107 & 101 & 116 & 112 & $81 * *$ & $73 * *$ & 6.59 & $<0.001$ \\
\hline Leucine & 150 & 144 & 148 & 140 & 163 & 149 & 3.18 & $<0.001$ \\
\hline Lysine & 104 & 107 & 101 & 101 & 99 & 107 & 6.82 & 0.11 \\
\hline Methionine & 121 & 134 & 150 & 124 & 108 & 118 & 5.94 & 0.007 \\
\hline Met+Cystine & 104 & 106 & 100 & 107 & 96 & 99 & 8.30 & 0.144 \\
\hline Phenylalanine & 152 & 165 & 163 & 100 & 88 & 100 & 12.47 & $<0.001$ \\
\hline Phenyla+Tyro & 135 & 150 & 150 & 133 & 122 & 135 & 4.42 & $<0.001$ \\
\hline Proline & 118 & 124 & 116 & 106 & 107 & 122 & 3.07 & 0.004 \\
\hline Threonine & 93 & 92 & 99 & $89 * *$ & 92 & $88 * *$ & 9.31 & 0.017 \\
\hline Valine & 100 & $83 * *$ & 104 & 106 & 112 & 129 & 9.27 & $<0.001$ \\
\hline $\begin{array}{l}\text { Suspected limiting } \\
\text { amino acid in diet }\end{array}$ & None & Valine & None & Threonine & Isoleucine & Isoleucine & & 0.05 \\
\hline
\end{tabular}

Table 7: Computed chemical score (\%) of protein in analyzed finished broiler finisher starter diets compared with recommendation for broilers aged 6-8 weeks*

\begin{tabular}{|c|c|c|c|c|c|c|c|c|}
\hline Nutrients & $\mathrm{CF}_{1}$ & $\mathrm{CF}_{2}$ & $\mathrm{CF}_{3}$ & $\mathrm{CF}_{4}$ & $\mathrm{CF}_{5}$ & $\mathrm{CF}_{6}$ & SEM & P-value \\
\hline Arginine & 110 & 110 & 113 & 110 & 96 & 119 & 8.13 & 0.004 \\
\hline Glysine+Serine & 145 & 160 & 161 & 150 & 128 & 174 & 6.49 & $<0.001$ \\
\hline Histidine & 185 & 174 & 182 & 182 & 219 & 266 & 14.56 & $<0.001$ \\
\hline Isoleucine & 126 & 119 & 137 & 132 & 95 & 91 & 10.57 & 0.001 \\
\hline Leucine & 175 & 169 & 173 & 163 & 191 & 174 & 3.86 & $<0.001$ \\
\hline Lysine & 122 & 126 & 119 & 119 & 117 & 127 & 1.62 & $<0.001$ \\
\hline Methionine & 144 & 159 & 178 & 147 & 128 & 141 & 7.05 & $<0.001$ \\
\hline Met+Cystine & 125 & 127 & 120 & 128 & 115 & 118 & 2.14 & $<0.001$ \\
\hline Phenylalanine & 177 & 191 & 189 & 116 & 102 & 116 & 16.89 & 0.035 \\
\hline Phenyla+Tyro & 159 & 176 & 176 & 156 & 143 & 159 & 5.16 & $<0.001$ \\
\hline Proline & 141 & 147 & 139 & 126 & 128 & 146 & 3.67 & $<0.001$ \\
\hline Threonine & 102 & 100 & 107 & 97 & 100 & 96 & 9.05 & 0.053 \\
\hline Valine & 117 & 97 & 121 & 124 & 131 & 151 & 10.42 & $<0.001$ \\
\hline $\begin{array}{l}\text { Suspected limiting } \\
\text { amino acid in diet }\end{array}$ & None & None & None & None & None & None & & \\
\hline
\end{tabular}

* Note: Chemical scores based on NRC (1994) requirements for broilers aged 6-8 weeks

When compared against the recommendations for broilers aged 6 to 8 weeks (NRC, 1994), the results indicate that, based on chemical scoring of each finisher diet, no amino acids were suspected to be limiting. This means all the diets analyzed may adequately support optimum growth of the broilers aged 6 to 8 weeks. Thus, farmers using feeds may have a wide range of diets to select from at ages 1-3 and 6 to 8 weeks while selections of finished feeds may be critical at 3 to 6 weeks of age. The implication of the findings of the present study is that it may be helpful to indicate the age range of the broilers that could achieve optimal growth from diets on the labels. This is because the dietary requirements of birds varied according to the physiological age of the birds and this may help guide consumers in their choice of feed beyond the declared nutrient profile of the diets. It may also help farmers decide the best time to change from starter to finisher diets based on the available feed.

\section{CONCLUSION}

From this study, the nutrient composition of the commercial diets analyzed were found to be within the recommended levels for broilers at the starter and finisher phases. Also, at the various dietary protein levels observed in the test diets, most of the amino acids were either similar or in excess of the recommended values except for methionine + cystine which appeared to be generally lower in the test starter diets. Although, estimates of biological values of the dietary proteins were generally high, at least methionine plus cystine (1 to 3 weeks) and threonine, isoleucine or valine (3 to 6 weeks) were suspected to be the limiting amino acids in the diets analyzed for broilers while no amino acid was suspected to be 
limiting in test diets for broilers aged 6 to 8 weeks. The suspected limitations could have far reaching effect on the performance of birds, especially if not compensated for by other amino acids that were observed to be in excess in the diets. Thus, it may not be advisable to switch from starter to commercial diets at 3 weeks of age for most of the finished feeds. The utilization of synthetic form of other amino acids like threonine, isoleucine and valine may be considered in finisher diets, especially when targeting broilers aged 3-6 weeks. However, this needs to be subjected to biological tests using live broilers. It is was Beyond declaring the critical ingredient mass in the diets, it may be helpful to indicate on the feed labels the physiological age of broilers for which diets are expected to result in optimum growth.

\section{REFERENCES}

Adene, D. F. and A. E. Oguntade, 2006. The structure and importance of the commercial and village based poultry industry in Nigeria. FAO (Rome) study. October, 2006.

Association of Official Analytical Chemists (AOAC), 1990. Official methods of analysis. $15^{\text {th }} \mathrm{ed}$, Washington DC.

Aviagen, 2009. Arbor Acres broiler management guide. Published by Aviangen Incorporated, USA. www.aviagen.com. 63 pp.

Bregendhahl, K., Sell, J. L., Zimmerman, D. R., 2002. Effect of low-protein diets on growth performance and body composition of broiler chicks. Poultry Science. 2002, 81 1156-1167.

Bryden, W. L. and X. Li, 2004. Utilisation of digestible amino acids by broilers. RIRDC Publication No. 04/030. Rural Industries Research and Development Corporation.

Burnham, D., 2003. Utilizing L-Threonine in Practical Corn/Soy Broiler Diets. Ajinomoto Heartland, Inc., 2003, publication 6, 15 pp. www.lysine.com/pdf/review/paper 6 20031.pdf.

Corzo, A., McDaniel, C. D., Kidd, M. T., Miller, E. R., Boren, B. B., \& Fancher, B. I. (2004). Impact of dietary amino acids concentration on growth, carcass yield and uniformity of broilers. Australian Journal of Agricultural Research, 55, 1133-1138. http://dx.doi.org/10.1071/AR04122

Eits, R.M., R.P. Kwakkel, M.W.A. Verstegen and L.A. Den Hartog. 2005. Dietary balanced protein in broiler chickens. 1. A flexible and practical tool to predict dose-response curves. $\mathrm{Br}$. Poultry Sci. 46(3): 300-309.
Food and Agricultural Organization Statistics (FAOSTAT), 2012. FAO Statistics database. www.fao.org.

Ferguson, N. S., Gates, R. S., Taraba, J. L. Cantor, A. H., Pescator, A. J., Straw, M. L., Ford, J. M. and D. J. Burnham, 1998. The effect of dietary protein and phosphorus on ammonia concentration and litter composition in broilers. Poultry Science 77: 1085-1093.

GenStat, 2013. GenStat $16^{\text {th }}$ Edition. GenStat Procedure Library Release PL24.2. VSN International Ltd.

Ikpi, A. and J. Akinwumi, 1981. The future of the poultry industry in Nigeria. World's Poultry Science Journal, Vol. 37(01): 39 - 43.

Llames, C. and J. Fontaine, 1994. Determination of amino acids in feeds: Collaborative study. J. AOAC Int. 77:1362-1402.

Manyong, V. M., A. Ikpi, J. K. Olayemi, S. A. Yusuf, R. Omonona and F. S. Idachaba (2005). Agriculture in Nigeria: Identifying Opportunities for Increased Commercialization and Investment. IITA, University of Ibadan and USAID/Nigeria.

Miller, E. L. 2004. Protein nutrition requirements of farmed livestock and dietary supply. In "Protein sources for animal the feed industry", Proceedings of Expert Consultation and Workshop, Bangkok, 29 ${ }^{\text {th }}$ April $-3^{\text {rd }}$ May, 2002. FAO Animal Production and Health Series, Published in 2004. pp 29-75.

National Research Council (NRC), 1994. Nutrient requirements of poultry. Ninth edition. National Academy Press, Washington, D. C. ISBN 0-309-59632-7, 176 pp.

Nakaue, H.S. and G.H. Arscott. 1991. Feeding Poultry. In: Livestock Feeds and Feeding. 3rd Ed. D.C. Church, Ed. Prentice Hall. Englewood Cliffs, New Jersey.

Neto, M.G; Pesti, G.M.; Bakalli, R.I., (2002). Influence of dietary protein level on the broiler chicken's response to methionine and beanie supplements. Poultry-Science. 2002. 79: 1478-1484.

Okoli, I. C., Nweke, C. U., Okoli, C. G. and M. N. Opara, 2006. Assessment of the mycoflora of commercial poultry feeds sold in the humid tropical environment of Imo State, Nigeria. Int. J. Enviorn. Sci. Tech., 3: 9-14.

Patterson, P, 2001.Using dietary and management strategies to reduce the nutrient excretion of poultry. Lesson 11, Reprinted from Livestock and poultry environmental stewardship curriculum. Midwest Plan Service, Iowa State University, Ames, Iowa 50011-3080. 
Salehifar, E., Shivazad, M., Foroudi, F., Chamani, M., and R, Bahari Kashani, 2012. Reevaluation of digestible amino acids requirements of male and female broilers based on different ideal amino acids ratios in finisher period. Annals of Biological Research, 3 (3):1362-1368.

Sugahara, M., D. H. Baker, and H. M. Scott. 1969. Effect of different patterns of excess amino acids on performance of chicks fed amino acid deficient diets. J. Nutr. 97:29.

USDA, 2002. Nigeria poultry and products - Poultry update 2002. Foreign Agricultural Services, Global Agricultural Information Network (GAIN) Report \#N12025. 